\title{
A COMPUTER CODE FOR CALCULATING PERSONNEL DOSES DUE TO TRITIUIM EXPOSURES
}

Curtis L. Graham

Joseph R. Par1agreco

Eebruary 2, 1977

Prepared for U.S. Energy Ausearch \& Developinent

Administration under contract No. W-7405-Eng-48

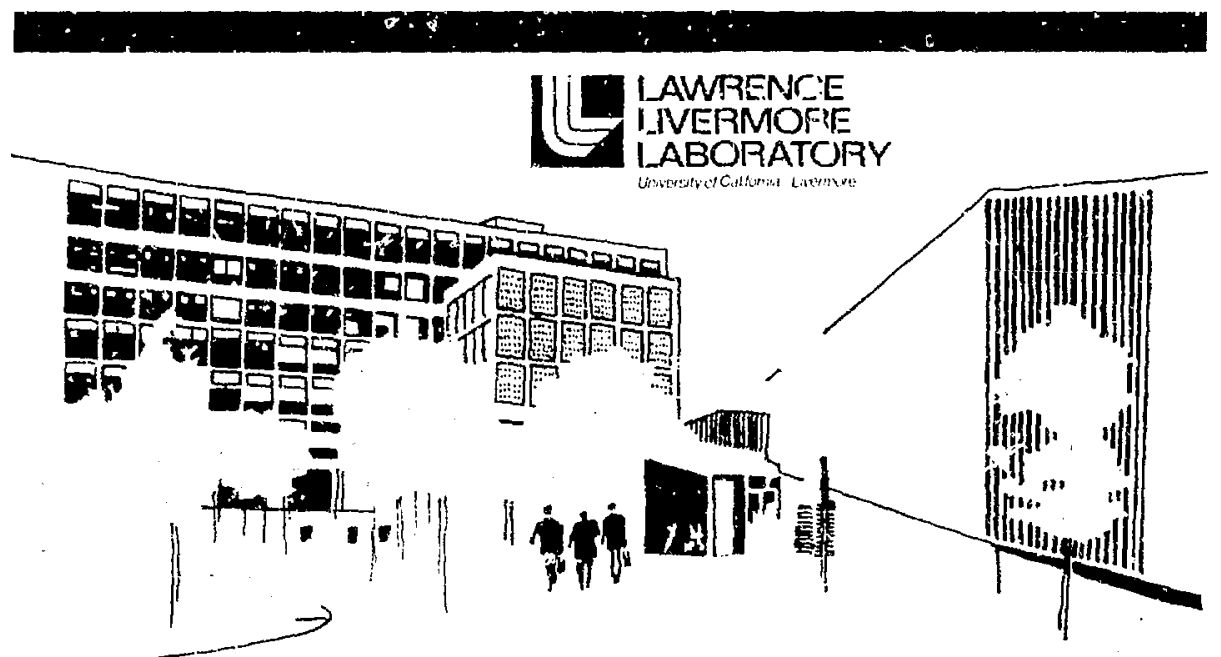




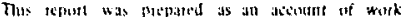

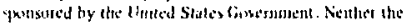

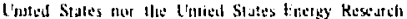

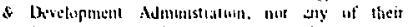

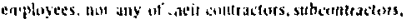

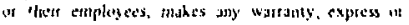

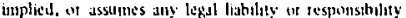
for the scturacy, completeress or usefulness of any

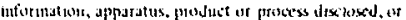
represents that its ise would not intinge mivalelyumated :

\section{NOTlit:}

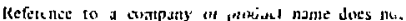
miply apposial is recommendation of the product by the Universty of Coltiotntis the U.S. Energy Reseatch \& Development Adminstratun to the exclusiosi of others that guar he stitzble.

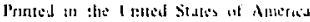

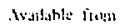

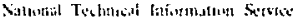

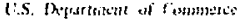

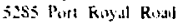

Spungtiuld. I'A $: 2101$

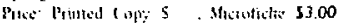

\begin{tabular}{|c|c|c|c|c|c|}
\hline Page & Ranges & $\begin{array}{c}\text { Domestic } \\
\text { Price }\end{array}$ & Page & Ranges & $\begin{array}{c}\text { Domestic } \\
\text { Price }\end{array}$ \\
\hline$\infty 01$ & 0.5 & 53.6 & 326 & $\because \leq 0$ & 161.00 \\
\hline $0 \geq 6$. & .050 & $\therefore(0)$ & 351 & 375 & 19.50 \\
\hline ust. & .075 & 4.30 & 376 & $\$ 100$ & 10.75 \\
\hline 076 & 100 & $\sin$ & +01 & +25 & 11.00 \\
\hline 101 & 125 & 5.50 & +26 & +50 & $1: .75$ \\
\hline 126. & .150 & 6.00 & 451 & 475 & 12.00 \\
\hline $15 !$ & 175 & 6.75 & $4: 6$ & sct & 12.50 \\
\hline 176 & 200 & 7.50 & 501 & 525 & 12,5 \\
\hline 201 & -225 & 7.75 & 526 & 550 & 13.00 \\
\hline 226 & 250 & 8.00 & 551 & 575 & 13.50 \\
\hline $251-$ & -275 & 4.110 & 576 & 6019 & 13.75 \\
\hline 276 & .300 & 9.25 & 501 & 193 & * \\
\hline 301 & 325 & 9.75 & & & \\
\hline
\end{tabular}

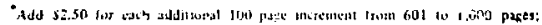

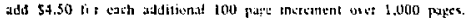




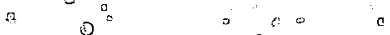

0

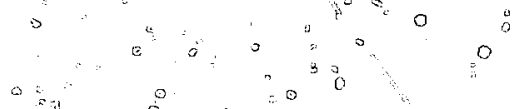

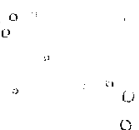

go

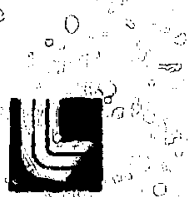

\title{
I_AMRENCE IJVERMOORE I_ABORATORY
}

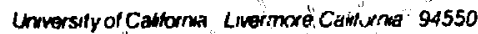

in

$\theta$

o
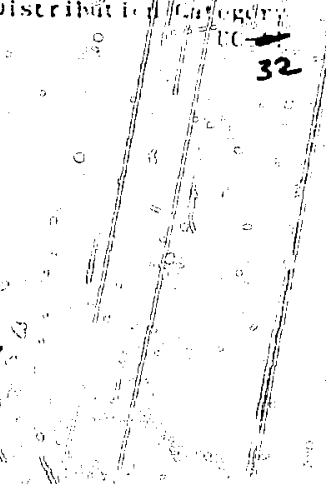

\section{A COMPUTER CODE FOP CALCULATING PERSONNEL DOSES DUE TO TRITIUM EXPOSURES}

I'CRT- $-5 ? 138$

\author{
Gurtis I. Graham \\ Olusent k. Parlagrweo
}

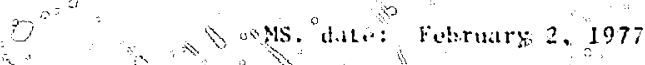
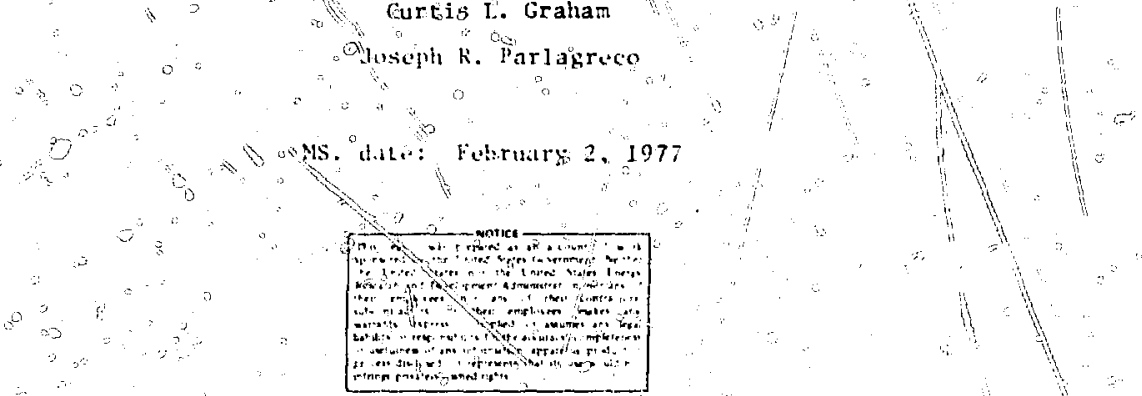


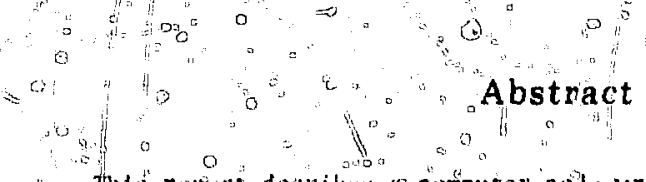

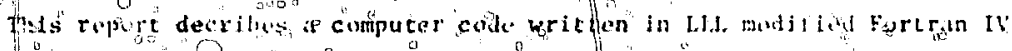

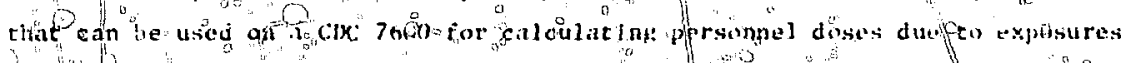

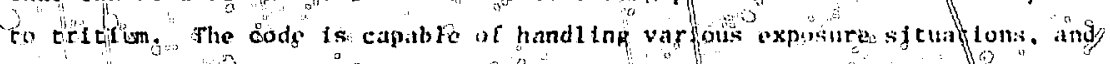

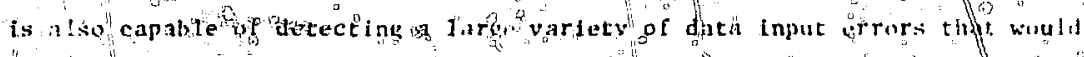
lewdrinerrors in theodose astossmont.
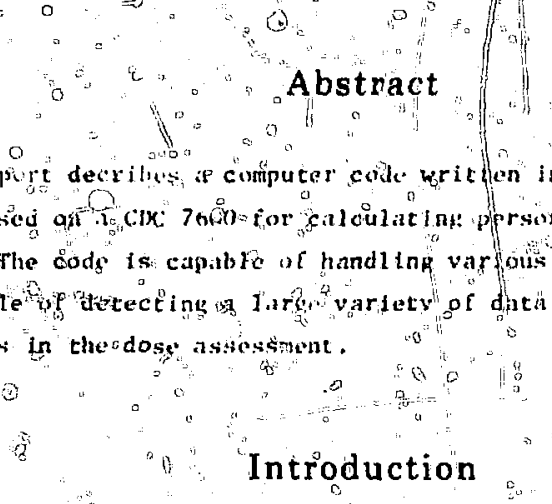

6

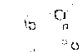

in

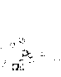

\section{Introduction}

Dis computer codt is useal tu calculate personich doses that accur for

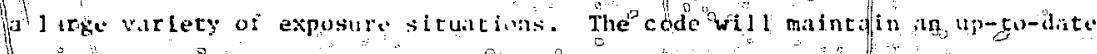

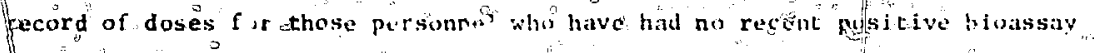
Hesults as well as those persopnel who bave chronle or acute exposuses co"

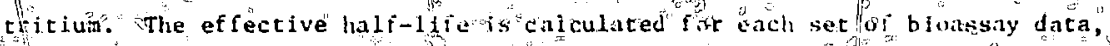
and is cianged when approprtate rov each computer run so thit each person is assigned the dose which corresponds $t$, his elininat lon ratc. The gode also checkswother the bioassay data are consistent with the copsoure category that was assumed for each persnn. If the exposure categnry is ant contistent With the blobay data, an error statement will appie on that frintout Explaining the crror. Thus, two primary sources of error, the exposure careghry and the effective half-liti assumplons, are minimized "line cyde wit also detect a variety of otier lnput errors. This code bffers good fledibilicy with good accuracy.

Fon acute exposures, the dose $r$ ate is assumed to follow a stople expongint in decay. For chronic exposures? the average dose rate fur the sampling period is assumed.

The printout incluoses many desirable categorles for personnel dosimetry records. Fersonnel are arranged by ID numbers on the printout which 1 lsts the doses for the present and previous year and quarter, the dose recelved 


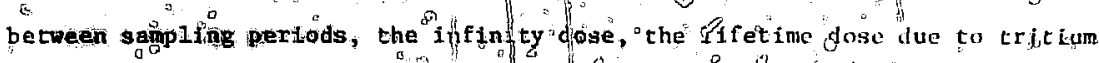
expogures, the eftective hal kifle, the last bioassay results sild sample day, and the exposure category ( $1_{j}, e .$, chronic $c^{\text {"or }}$ acute).

The dbde is written in LLL mpdifted Fortran ${ }^{\circ}$ TV which can be fiodified to ANSI FORTRAN IV.

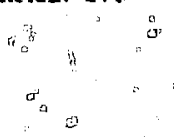

\section{Types of Exposüres,}

Exposures are divided into three groups:

Group 1: No known exposure has occurred between sample days.

Group' 1a: A known exposure has occurred, and the pripable

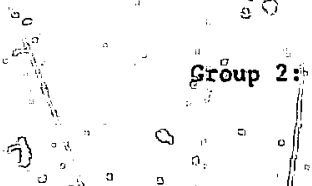
is known.

Definitions of symbots:

$C_{0}=$ ofd chncentration level (OLEV).

$C_{n}=$ new goncentratticn level (NLEV).

9 concentration level on day of known exposure.

o: $5_{0}$ old sample date $($ ODAY $) .0$

t $=$ new sample date (NDAY).

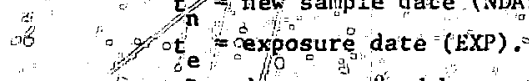

D d dose recefived between to and $\mathrm{t}_{\mathrm{n}}$ (mrem/sample).

Do jnfinify dos (doseg that will be received at

" teimes greater thañ " If no further exposures occux) (mrem/INF).

MRQ/ $=$ mrem received on the present quarter up to the last sampes ${ }^{\circ}$,

O/f date.

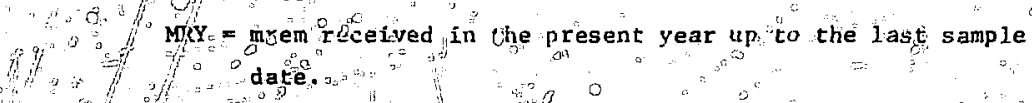

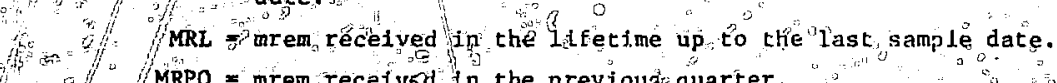

$M R P Q=$ mrem recelved $\frac{1}{n}$ the previoust quarter.

MRY $=$ mrem recelved $t_{\mathrm{h}}$ the prey cous year.

$T=$ effective half- Ife for tritiated water $\left(\mathrm{T}_{1 / 2}\right)$.

Tezms parenthesis are" used for fomputer printout. 


\section{General Caliculátions}

10. The articteal organ ts the pody water. The Quality Factor for tritium is " $1: 0.1$ The density of body" tissue is assumed to/be 1.0 .

The dose-eguivalent rate (nipem/day) is:

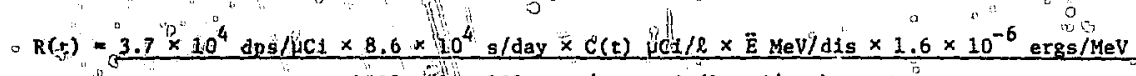
Cu $\quad 01000 \mathrm{~g} / \mathrm{h} / 100 \mathrm{rgs} / \mathrm{g} \cdot \mathrm{rad}(1 \mathrm{rad} / \mathrm{rem})$

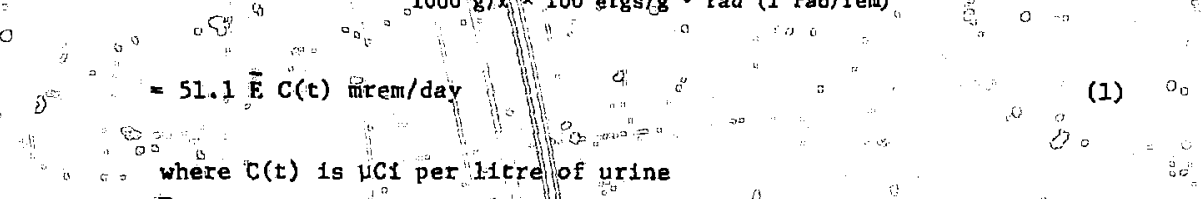
$\bar{E}_{p=0}=0.0057 \mathrm{MeV}$

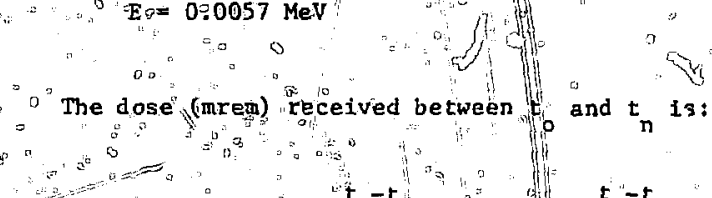

$\frac{0}{0}=0$

a $\quad \therefore$ a

$D=\int_{0}^{t} \int_{0}^{-t} R(t) d \tau=\int_{0}^{t-t} 0$

$51.1 \overline{\mathrm{E}} \mathrm{C}(\tau) \mathrm{d} \tau$

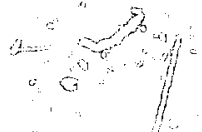

" 0

$=$

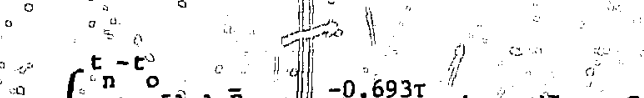

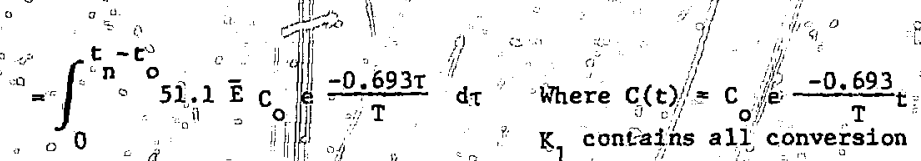

$j \quad Q^{2}$

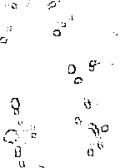

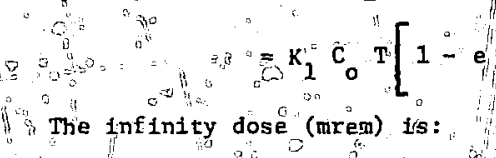

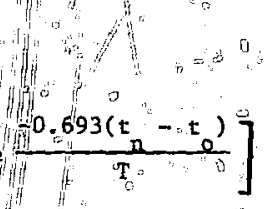

$\mathrm{K}_{1}$ contatins all conversion constants. $K_{1}=0.42 \mathrm{mrem} /$ $\mu \mathrm{Ci} / \mathrm{l} / \mathrm{day}$

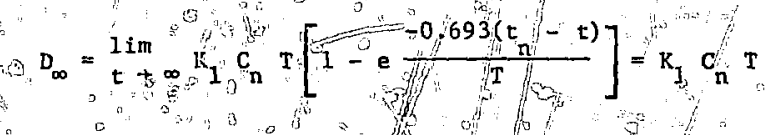

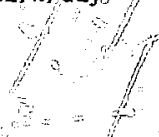

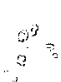




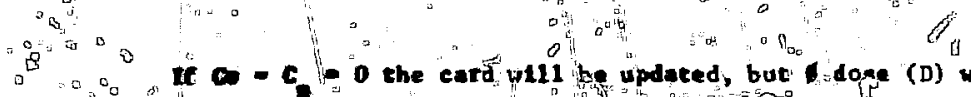

\section{the prinsolet.}

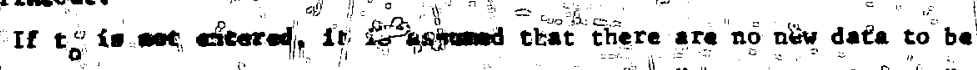

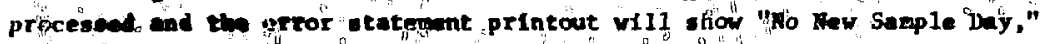

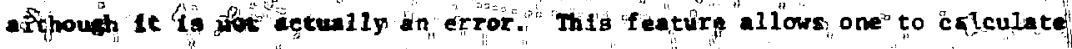

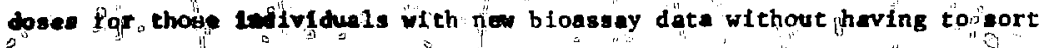
thoa individele $\rho$ carde from the whole eroup. If new data a re acquired, it need only be entered in the appropriate spaces on the cistrd.

For all error ptintouts, the nam, ID number (and $v_{0}, c_{n}, t_{0}, t_{n}$ will Binted wtir the type of error.

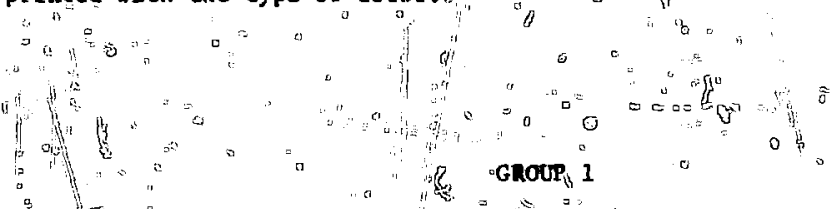

fo expocure has occurred between gample dates.
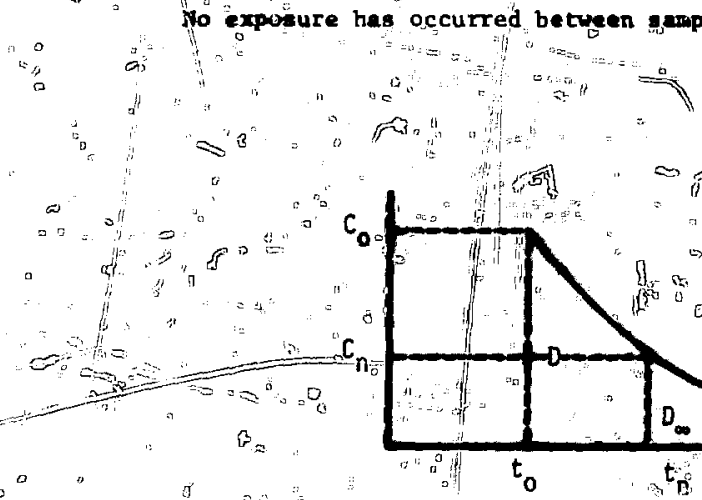

,
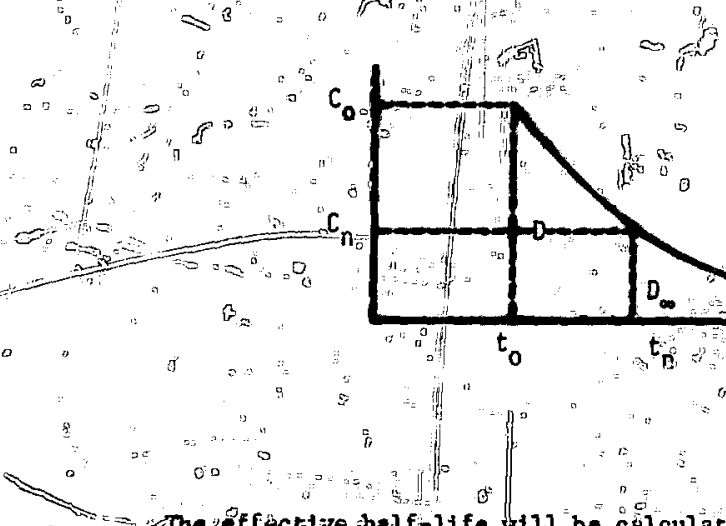

a The dffective half-life H11 be calculated. If $T>12$ daye or $T<4$

क days, the assuption that no epposure has occurred ibetween $t$

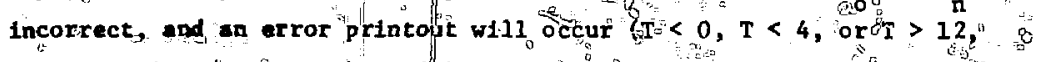
whichever Io aṕpropiate). If $4<\mathrm{T}<12$, "D and $\mathrm{D}_{\infty}$ will be calculated bys Hsing the newy calculated $T$ which wili also be entedred on the new computer "orara and printout." $\int_{t=0}^{\infty}=0$

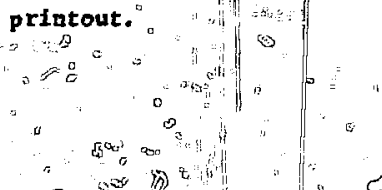
$-5-$ 


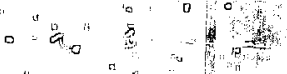

8

2

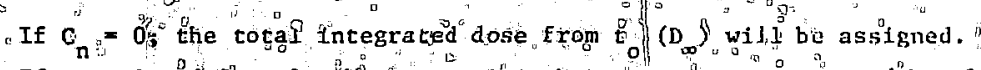

off $\mathrm{C}_{0}=0$ and $\mathrm{C}_{\mathrm{n}}>\mathrm{Q}_{\mathrm{O}}$, the assumption that no exposure occurred" between

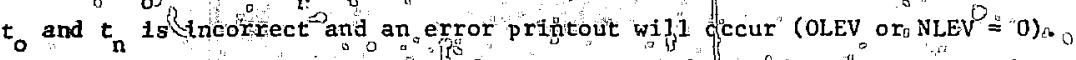

The half-life ( $T$ ) is calculated as follews:

The slope of the line in the above figure is equal to the degay constant $(\lambda)$.

$$
\lambda=\frac{l_{0}-\ln ^{2} c_{n}}{t_{n}-t_{0^{0}}}=\frac{1 n c_{0} / c_{n}}{t_{n}-t_{0}}
$$

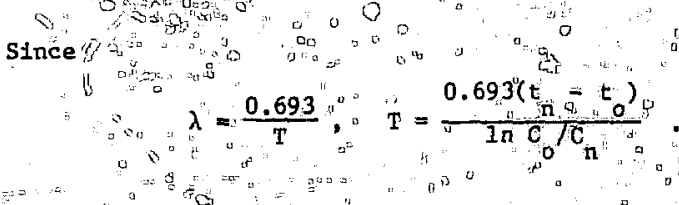

$$
\begin{aligned}
& \text { GROUY la }
\end{aligned}
$$

5

A known exposure has occurred, and the probable day $(t)_{0}$ is known.

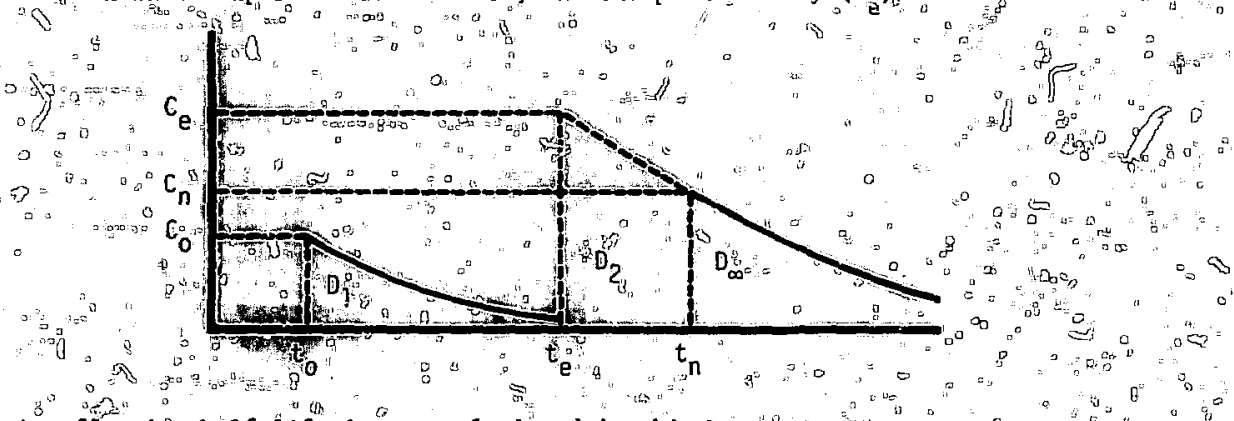

Ag effective half-ilife is not calculated in this case.

The concentration ( $(C)$ that resulited trom ${ }^{\circ}$ tritium exposure on day

(t $t_{\mathrm{e}}$ is cajculated as shownj below.

If $\mathrm{C}_{\mathrm{n}}=0,0^{\circ}$ the assumption that an exposưe has occurred between "to ard

$t$ Ig incorrect and an error printout w111 occur (EXP $>0$ and NLEV = 0).

$$
\begin{aligned}
& \underset{\gamma e}{c}=c_{n} e \frac{0.693\left(t_{n}-t\right)}{T}
\end{aligned}
$$

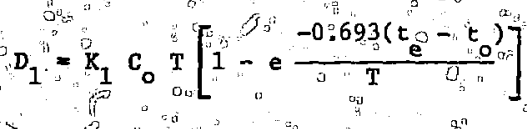




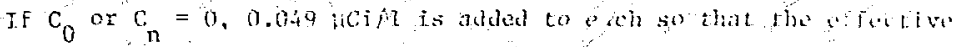

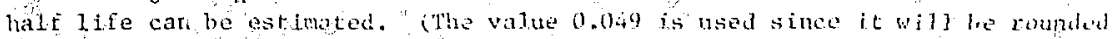

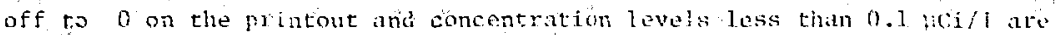
entered 25,0$)$. Depending upon the est imated valuo of 7 , either an orror

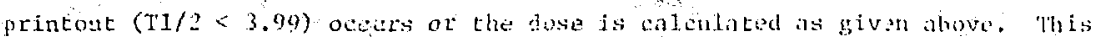
- is done to give the hest estimato of the dase (ll) when $f_{0} \neq 0$ and $l_{n}=0$. bi is culculated as:

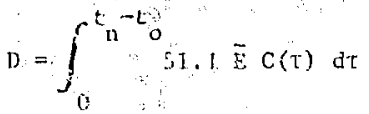

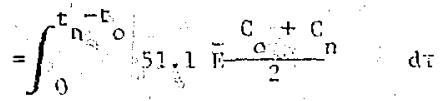

$$
\begin{aligned}
& =\mathrm{A}_{2} \frac{\mathrm{c}_{\mathrm{n}}+\mathrm{c}}{2}\left(\mathrm{t}_{\mathrm{n}}-\mathrm{t}_{0}\right) \quad \text { where } \mathrm{k}_{2}=0.29 \text { (mrem/ucj/R-days) } \\
& \mathrm{L}_{\infty}=\mathrm{k}_{1} \mathrm{C}_{n} \mathrm{~T}
\end{aligned}
$$




\section{Appendix A:}

11 the quartor romes gotween $t_{0}$ and $t_{i}$, the dose (D) is calculated as:

7) Jose in the previous quartes (year)

$D_{n}=$ dose in the prefint quarter fyear)

!) = the quarcer datio $190,181,273,366$ days)

$D=10+3$

For Gtau 1:

$$
\begin{aligned}
& { }_{0}=0.42 c_{0} T\left[1-e \frac{-0.692\left(n-\tau_{0}\right)}{T}\right] \\
& { }_{n}{ }_{n}=0.42 c_{0} T e \frac{\left.-0.693(1)-\tau_{0}\right)}{T}\left[1-e \frac{-0693(t-0)}{T}\right]
\end{aligned}
$$

il $C_{n}=0$

$$
\begin{aligned}
& D_{0}=0.42 c_{0}\left[1-e \frac{-0.69 j\left(0-t_{0}\right)}{T}\right] \\
& D_{I}=0.42 c_{0} i-D_{0} .
\end{aligned}
$$

For Group la:

i. $: t_{t}<\eta<t_{n}$

$$
\begin{aligned}
& D_{0}=0.42 C_{0} T\left[1-e \frac{-0.693\left(t_{e}-t_{0}\right)}{I}\right] \\
& +0.42 c_{\mathrm{e}} \mathrm{T}\left[1-\mathrm{e}^{-0.693\left(0-\mathrm{t}_{\mathrm{e}}\right)}\right] \\
& D_{n}=0.42 c_{e} T e \frac{-0.693\left(2-t_{e}\right)}{T}\left[1-\frac{-0.693(t-Q)}{T}\right]
\end{aligned}
$$




$$
\begin{aligned}
& \text { ff. } \\
& \text { If } t_{0}<Q<t_{e} \\
& D_{0}=0.42 C_{0} T\left[1-e \frac{-0.693\left(Q-t_{0}\right)}{T}\right] \\
& D_{n_{1}}=0.42 c_{0} T e \frac{-0.693\left(Q-t_{0}\right)}{T}\left[1-e \frac{-0.693\left(t_{e}-Q\right)}{T}\right] \\
& +0.42 c_{e} T\left[1-\frac{-0.693\left(t_{n}-t_{e}\right)}{T}\right]
\end{aligned}
$$

For Group 2:

.'t.

$12:$

$$
\begin{aligned}
& D_{0}=0.29:\left[\frac{C_{0}-C_{0}}{t_{n}-t_{0}}\left(\frac{Q}{2}\left(\frac{t}{2}\right)+C_{0}\right]\left(Q-t_{0}\right)\right. \\
& D_{n}=0.29\left[\frac{C_{n}-C_{0}}{t_{n}-t_{0}}\left(\frac{Q-t_{n}}{2}-t_{0}\right)+c_{0}\right]\left(t_{n}-Q\right)
\end{aligned}
$$

5

$-10-$ 


\section{Appendix B}

\section{ERROR STATEMENT}

*****:

SAITH B
OLD SAMP1SE LLVEL =
OLD SAMPLE DAY
123457

OLI) SAMLLE DAY

10. NEW SAKPLE LEVEL = 10

100 NEW SANPLE DAY

123457 SMITH B

ERROR IS $\mathrm{Tl} / 2>12$

$* t x+\leqslant x$

SMITH C

123458

OID SAMPLE LEVEL

10 NEW SARPLE LEVEL :-

OLD SAMPLE DAY

100 NEV SAMPEE DAY

$\$ 23458$

ERROR IS $1 \mathrm{i} 1 / 2>0$

$* \star \star \star * \star *$

SMITH B

123460

OLD SAPTLE LEVEI,

100 NEW SAMPLE LEVEL = 10

OLD SAMPLE DAY

100 NEW SAMPLE DAY

123460 SMITH B

ERROR IS $\mathrm{T} 1 / 2<4$

$x+x+t$

SMITH $F$

123461

OLD SARPLE IEVEL =

OO NEN SAMPE EEVEL =

20

OLD SAMPLE DAY

100 NEW SAMPLE DAY

123461 SNITH $\mathrm{F}$

ERROR IS OLEV OR NLEV $=0$

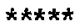

SMITH $\mathrm{K}$

123466

OLD SAMPLE LEVEL =

10 NEW SAPPLE LEVEL =

OLD SAMPLE DAY

J.0O NEW SAMPLE DAY

130

123466 SHTTH K

ERROR IS EXP $>0$ AIID NLEV $=0$ 


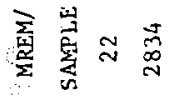

$$
\begin{aligned}
& \text { 毫- } \\
& \underset{\sim}{\sim} \text { a }
\end{aligned}
$$

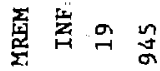

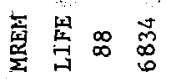

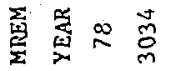

$$
\begin{aligned}
& \text { 菱 希? }
\end{aligned}
$$

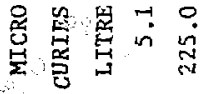

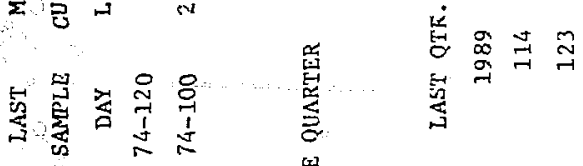

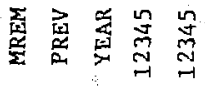

$$
\begin{aligned}
& \text { 器 }
\end{aligned}
$$

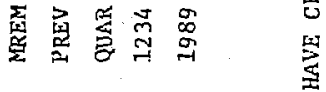

$$
\begin{aligned}
& \text { 总总总 }
\end{aligned}
$$

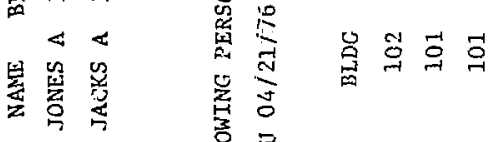

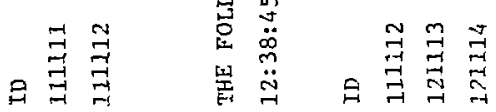




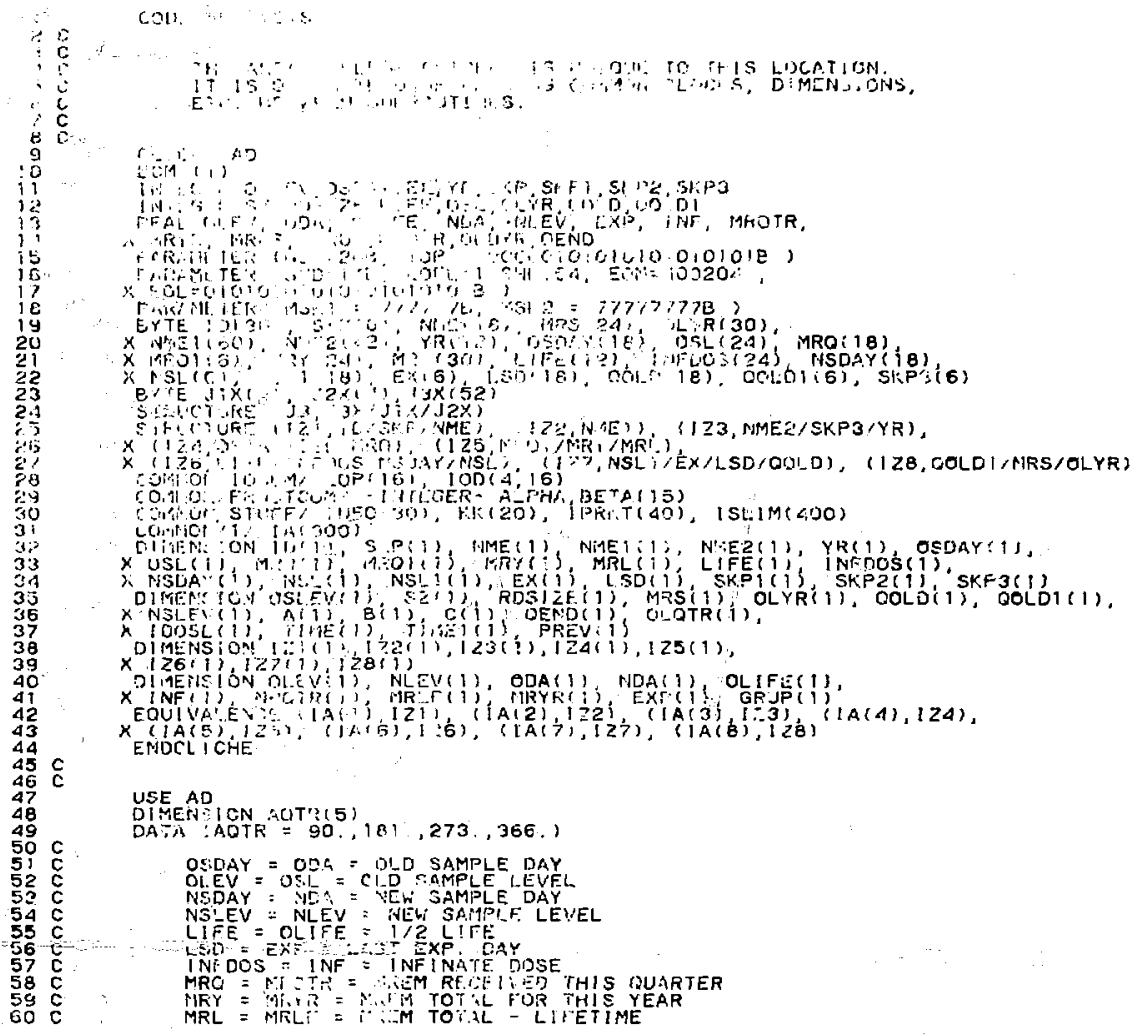


OA $\hat{O}_{L}=$ ERL

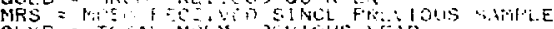

OLYR = TL TAL PIRLN, REYIUUS IEAR

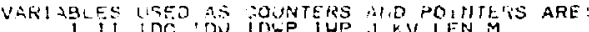

LINE ? TU LINE 209

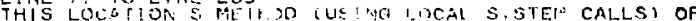

SETTING UP I O FILES DRTA IS NLAD IN, COLNTEO, SORTED AND WFITTEN SUT TO A NEW FILE.

CREATE LIFIOH" FILE

CALL C J C

is $=J 2+35252513$

TFP = (ISRTRIT) SHL. 18) UN. J2

FROST (IOOB, 1 , TPP, $O$, ERI)

CALI INIO

$I O R=1 O \mathrm{~W}=1 \mathrm{WWP}=1 \mathrm{WP}=0$

$K V=9$

$t=1 S=$ I

BETA = 25HTY'TE FILE NAME ANO RJET

CALL MESSAGE (SND, $0,3,1, F I N$ )

CALL MESSAGE (GET, 0, 2, $1, F I N)$

MASTER = BETA(1)

BCDOCT (BETA(2) J3 73 )

$\mathrm{TP}=626000004146 \times 107070 \mathrm{~B}$

$\mathrm{j3}=\mathrm{j} 3+120 \mathrm{~B}$

$J 4=J 1 x+4 j 3$

$J 5=J 2 X+418$

$T P=(T P \cdot U N \cdot(J 4, S H L \cdot d R) \cdot$ INI. $(J 5,\{H L .36))$

IOD 5 = INPUT (MASTER) (OLD CARDS)

$1006=$ DOTRIX

IOD $7=$ OUTPUT 1 TFA) (NEW CARDS)

IOD $B$ = PRINTER (PRNT)

IF (BETA 1 ) EO EOM) GO TO 1

22 NUOUT $=$ (MASTER. SHL .6). INT, (77777777777777777700B), UN, IR* INFO $(1)=4 R T R I X$

GENERATE AN IIISTFICTION FILE FOR TRIX

TO WORK ON, IN THIS CASE, SORT THE INCOHONG FILE: BY ID

NUPBER AND OREATE 'A NEW' DATA FILE.

INFO(2) $=0$

INI TIALIZE TRIX

(DATA MANIPULATION ROUTINE)

FROST (22B, $0,0,0,1 N F O, E R 8)$

SEND MESSAGE TO TRIX 


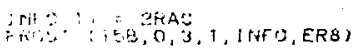

(A... C. C. IEY ID NISTER)

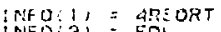

INFOI? = ENL

INFOIS: = MASTER

INFO(A) = EOL

J H. $0: 5)=$ MUUUT

(N.FO $($ B) $=$ EOL

INFO $(5)=A R, \cdot 6$

(NFOA $A\}=E O$

INFO(S) = EOFL

CREATE FILE FUR TRIX COMMANDS

ACCESS (1, 6RDO $(1: 1 \times, 6,0,20$, ER4)

SETJO $(6,9$, INAF $0,6,413 B\}$

REIO $(6, i, 0)$

CLUSE FILE

ACCFSS (19, OROOTRIX, $6,1,0$, ER4)

NFO(1) $=$ i DHRD(DOTRIX)

INFO $(2)=$ EOL.

TROST (15E,0,3, 2, 1NFO, ER8)

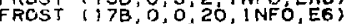

E7 INFO (1) = SREND

INFO( 2 ) $=E O L$

FROSI (158,0,3,2, INFO, ERB)

FROST (1FB; $0 ; 0 ; 20$, INFO, EA)

DPEN THE NEW SORTED DATA FILE. GET IT'S SIZE

AND USE IT TO CREATE A NEW OUTPUT FILE OF THE SAME SIZE.

THIS NEW JUTPUT FILE IS TO BE PUNCHED AND REUSED AS INPUT

FOR THE NEXT RUN.

E5 ACCESS ( 3 , NUOUT, $5,0,0$, ER5)

MSIZE = BETA(2):INT:77777777B

ACCESS ( $T$, TPA, 7, O, MSIZE+10, ER3)

INFO (i) = EOFL

INFO(2) $=\operatorname{INFO}(5)=0$

INFO ( 3 ) $=7 R B O X$ T3O

INFO (A) $=$ GRTRIT-DATA

SETIO $(7,5,1 \mathrm{NF}=0,7,413 \mathrm{~B})$

$S Z=M S: Z E+2$

REIO $\{7,1, S Z\}$

RDSIZE $=800$

IF (MSIZE

$G O$ TO 20

19 SETIO (5, RDSIZE, $\left.{ }^{\prime A}, 5,412 B\right)$

DESTROY DOTRIX

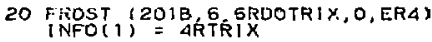




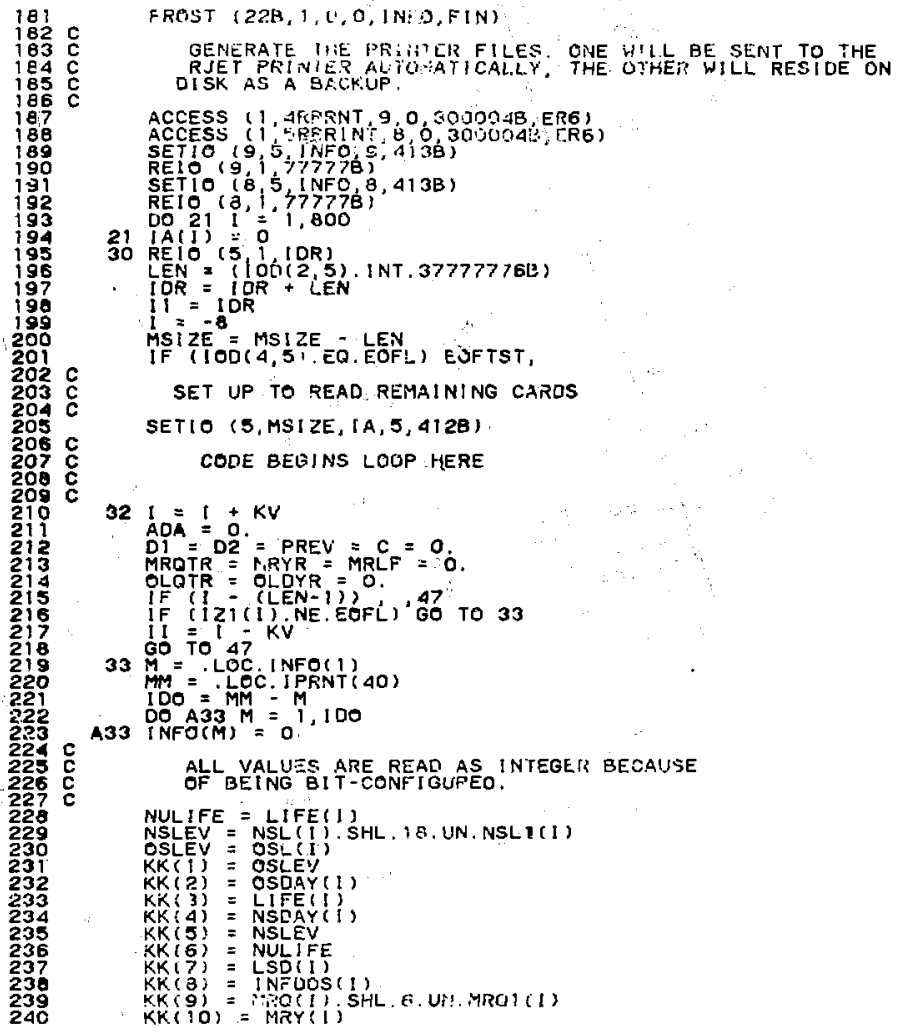




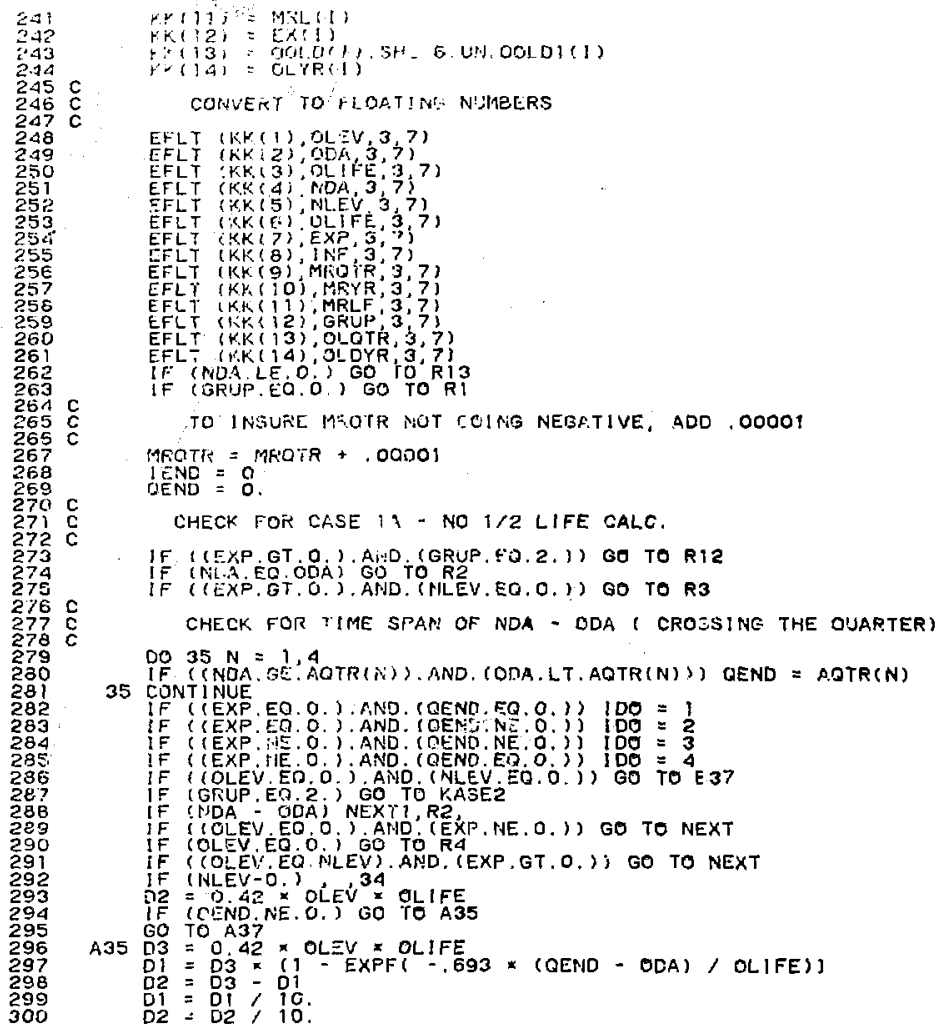




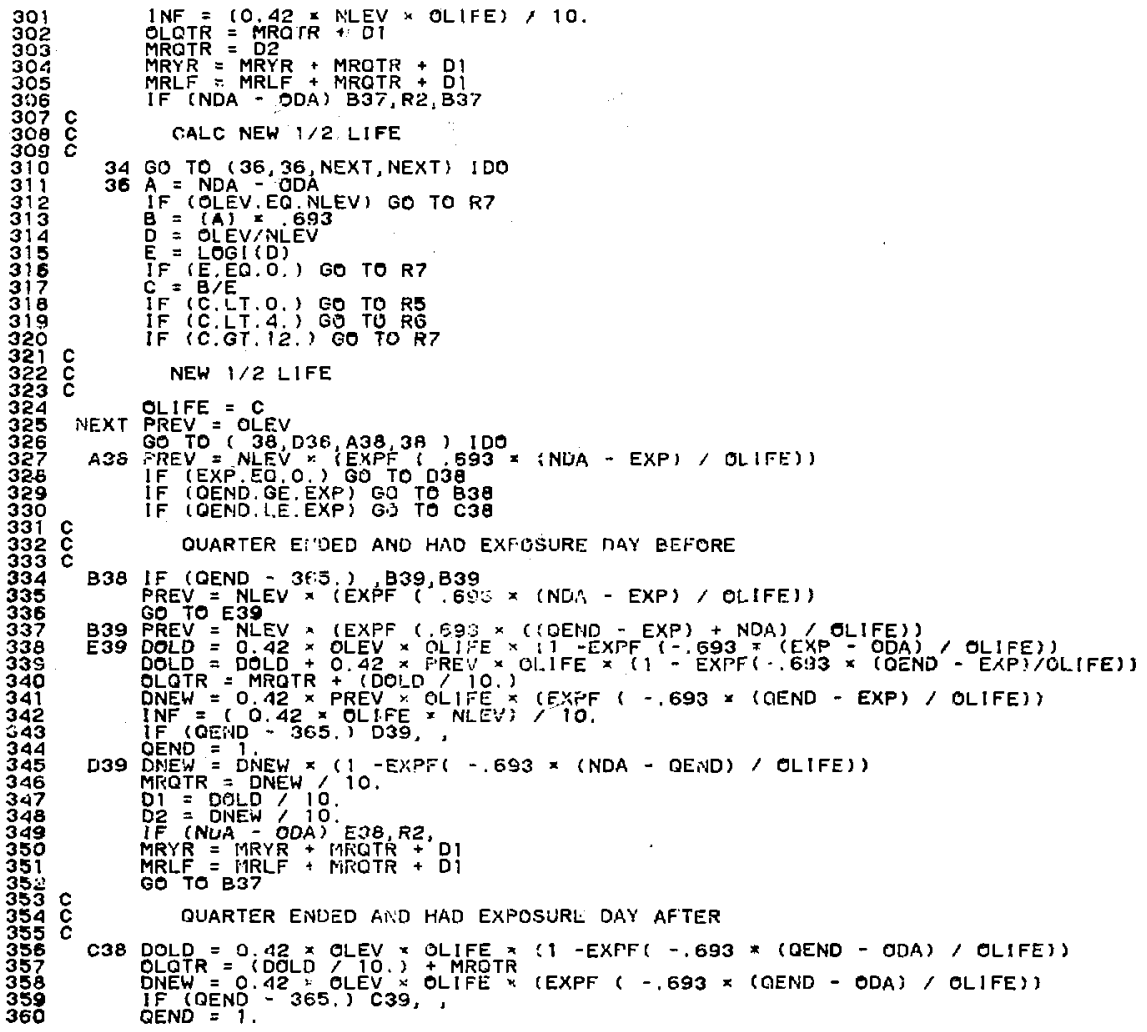




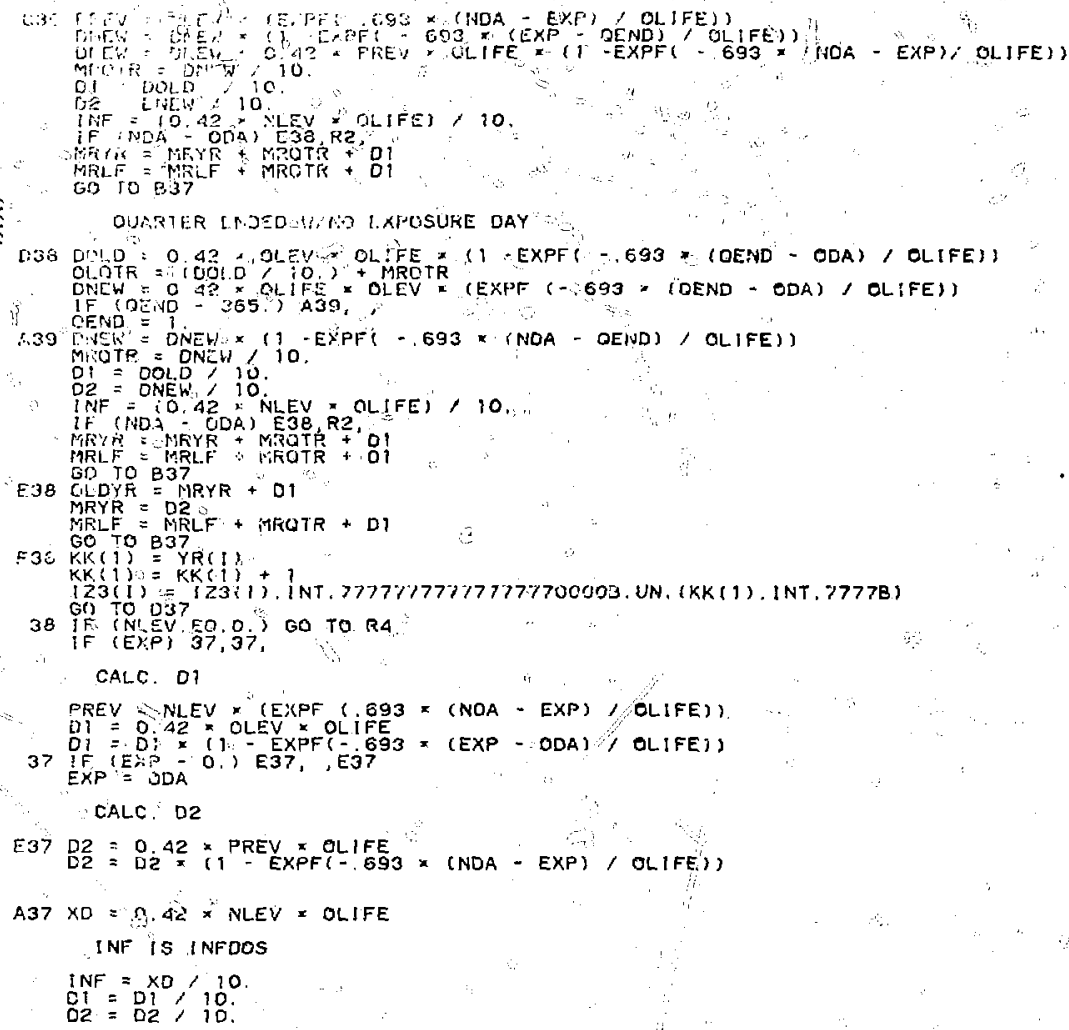




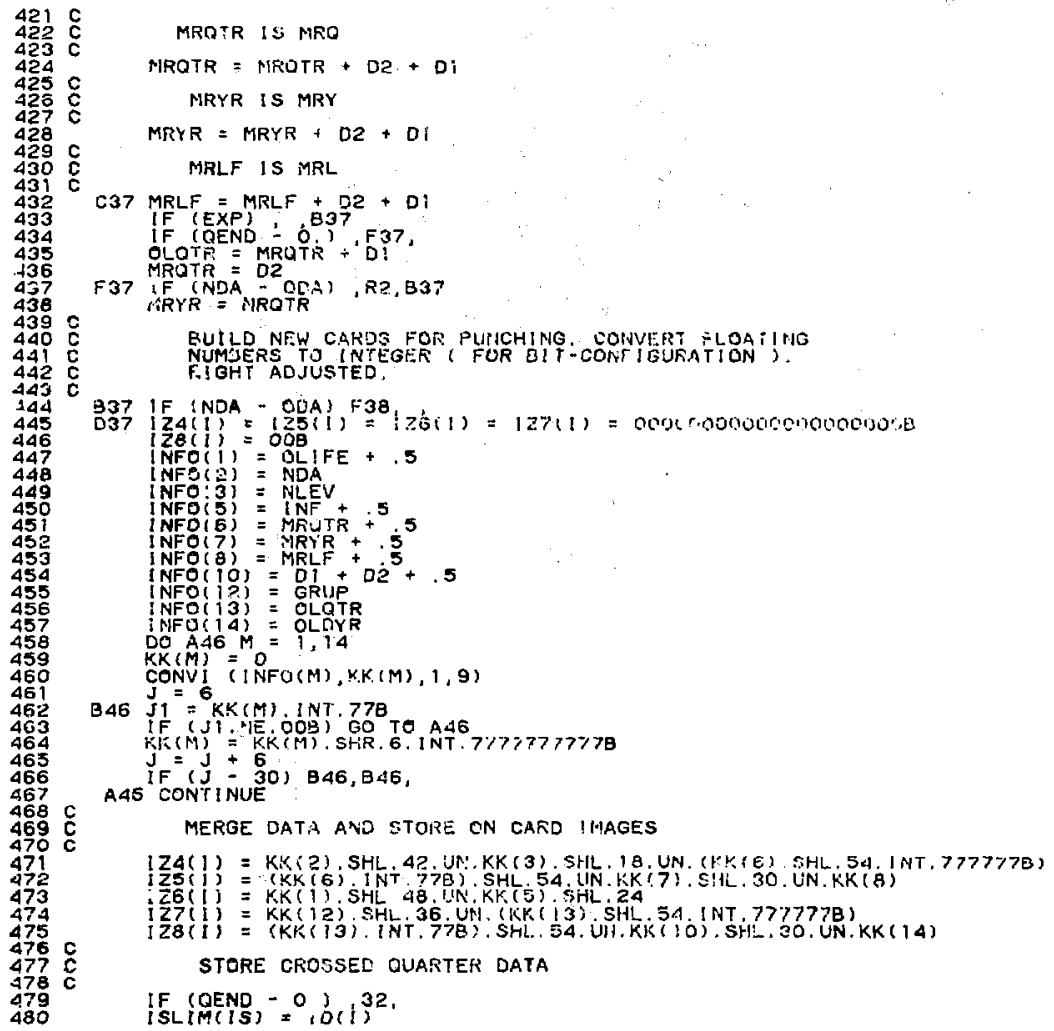




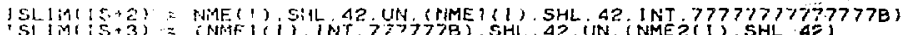

$489 \mathrm{C}$

य96 HLXTI IFLOL' - 366.), ,F

491 OEND $=336$

192

NHTS AOA $=((366 . '$ ODA + NDA $\times .693$

IF TERUP. EQ. 2 , GO TO NEXTA

IF (OI EV EO. NLLV EV GO TO R7

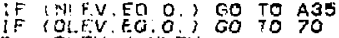

$D=O L E V, N L E V$

$E=\operatorname{LOG}$ ( $D$ )

IF (E.EO.O) GO TO RT

IF :GFUP. EO.Z ? 9070 NEXT7

iF (C.LT.O.) GO TO RS

if $(\mathrm{C}, 1, \mathrm{~T}, 4$,$) 60 TO R6$

$5 i 1$

IF 'C.GT IE, , 60 TO P.J

QEND $=3+6$.

SI 3 INEXTA IF (OLFV.EC . MLEV) GO TO 70

5 i4

$5 ! 5$

$5103: 17$

IF (ADA.LF. D.) GO TO NEXTB

518

5,9

520

GO TO NEXT

IF (C. LE. O. GO TO 70

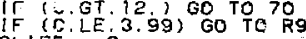

$O L I F E=C$

IF (QEEND

I: XT2 IF (EXP

SET UP FOH PRINTER

47 CALL HEAD

SETIO $(8,14$, (PRNT, $8,4 i 3 B$ )

529 
54 i

IPRNT $(14):=$ EOL

REWP 8 I DWP $+14=0$

REIO (9, $1,1,1,1)$

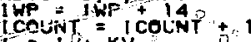

$5 e^{2}$

$\left.T^{2}=I\right\}+K V$

51 IPRNT $(M)={ }^{\prime}{ }^{1}$

IFRTT(M) $=0,0$, RELEOF

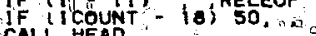

CALL HEDD

1 COUNT 50

END OF $F_{0}$ PRINIER

O END OF FILE COFIOITJUN TEST

RE 10 (S, $1,10 R$,

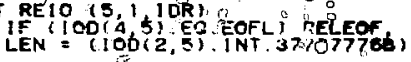

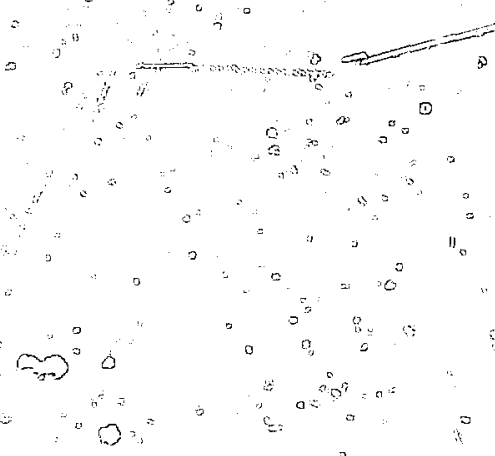

a 


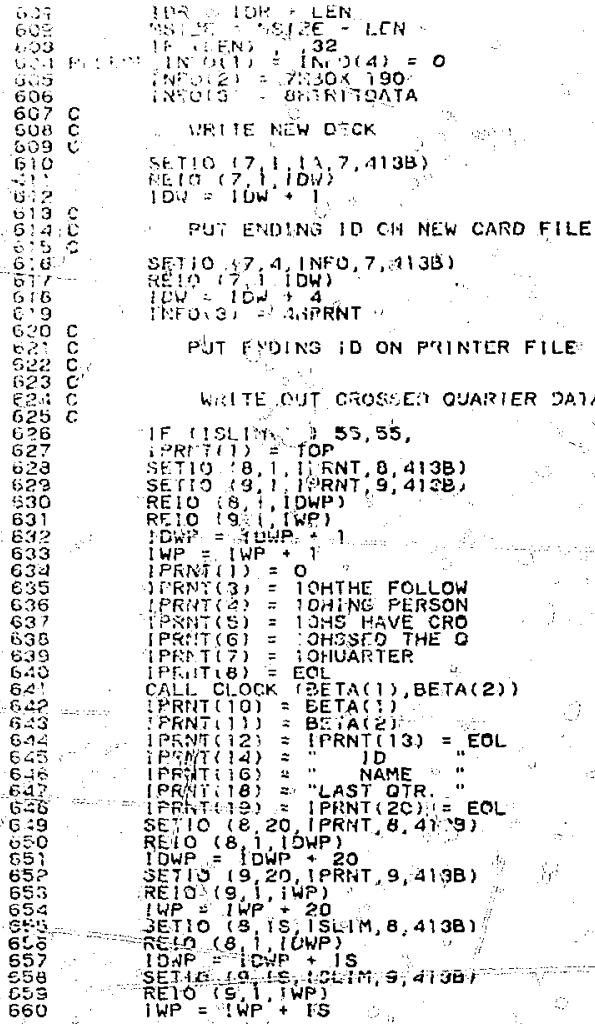




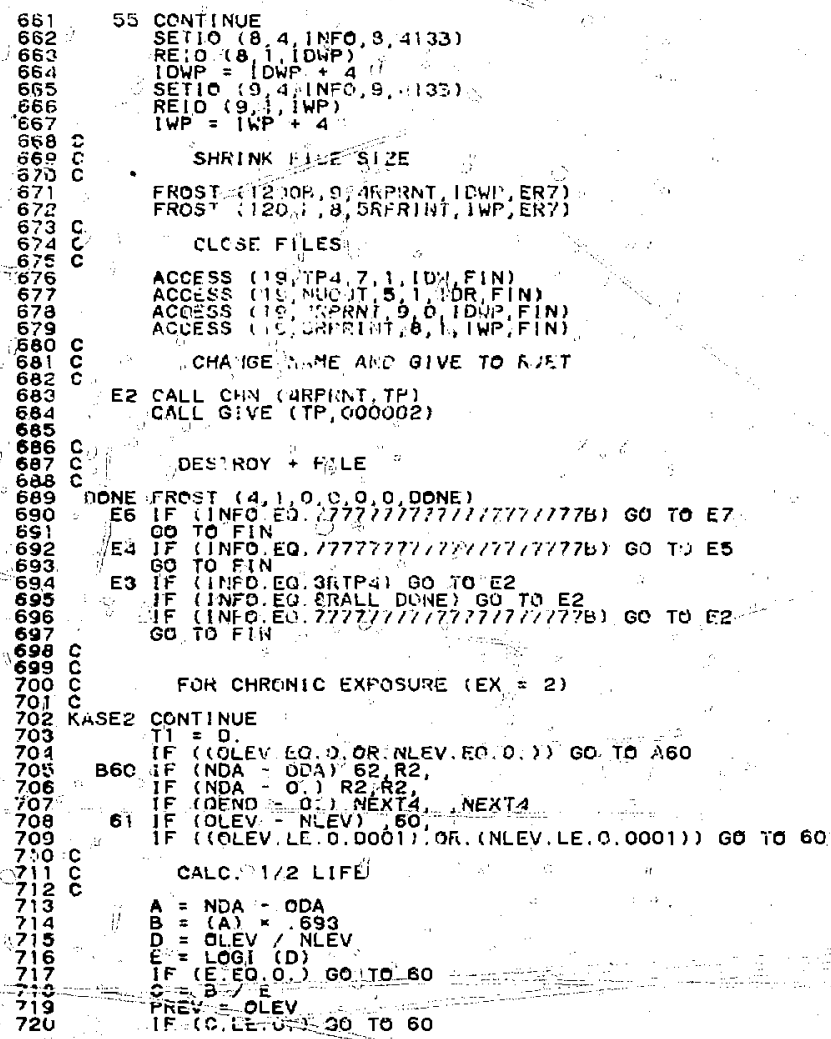




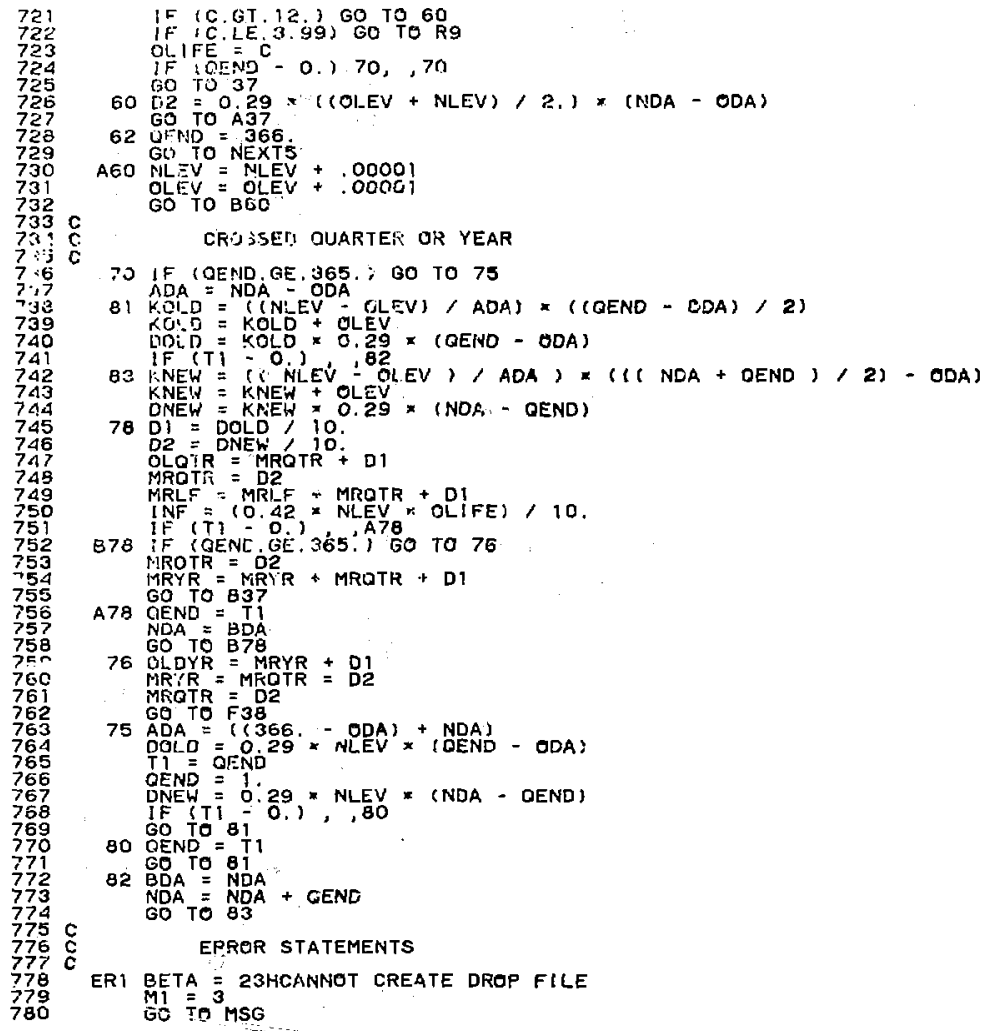




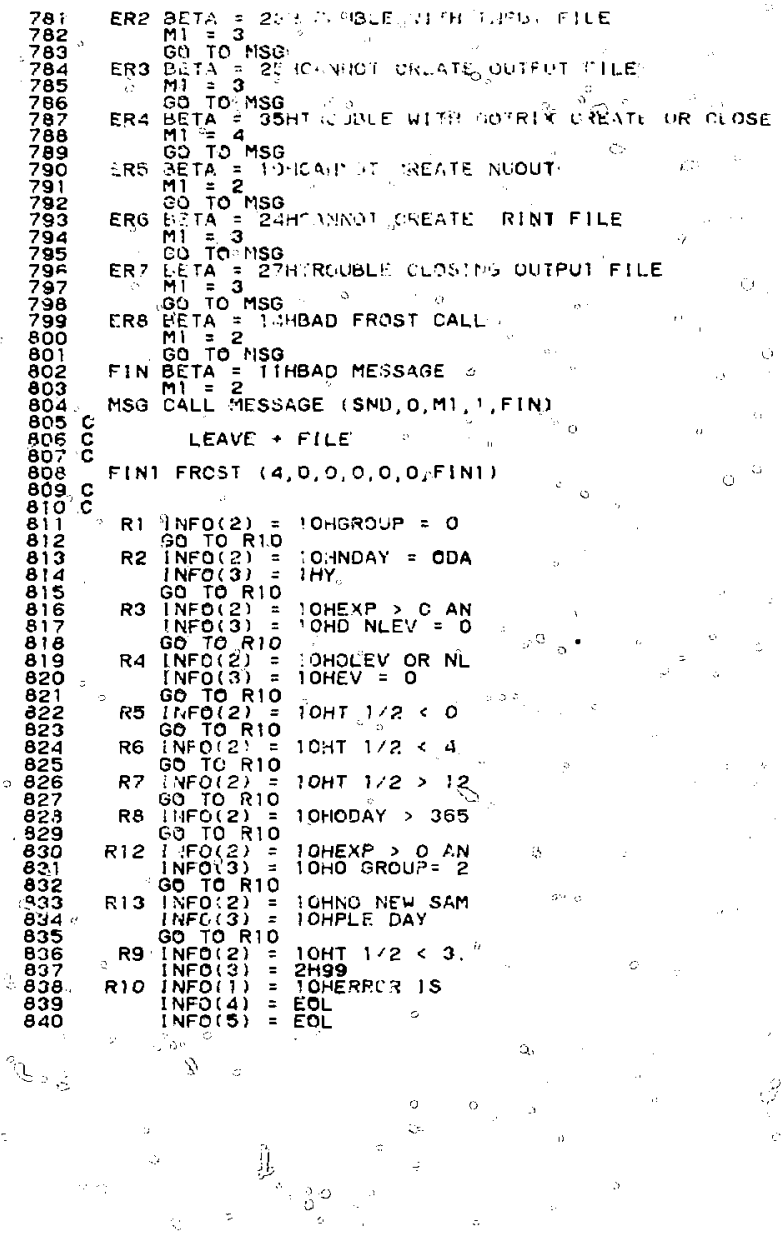


to:

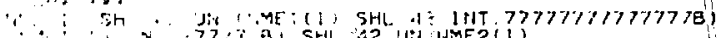

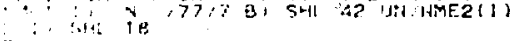

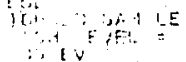

Iit

$\therefore \mathrm{E}$

i. $\%$.

$\therefore$, MP:

cint in

(ITAt)

$\therefore$ : oblets

o mat :

If $+1,26=$ EOL

$\therefore<. \therefore$ a

28

(2)

- ShP

$\therefore \cdot 28$

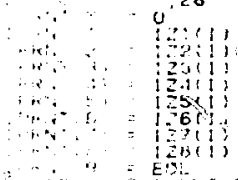

The

a i imp

$\therefore$ an ?

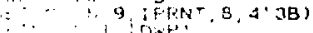

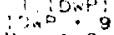

$\therefore \therefore=9$

(1)

ine?

nद

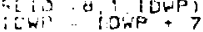

1 $3 \therefore=01.7$

$\therefore+32$

$\therefore<$

(1)

VEADER

$\because \because 1, \cdot$ MEA 


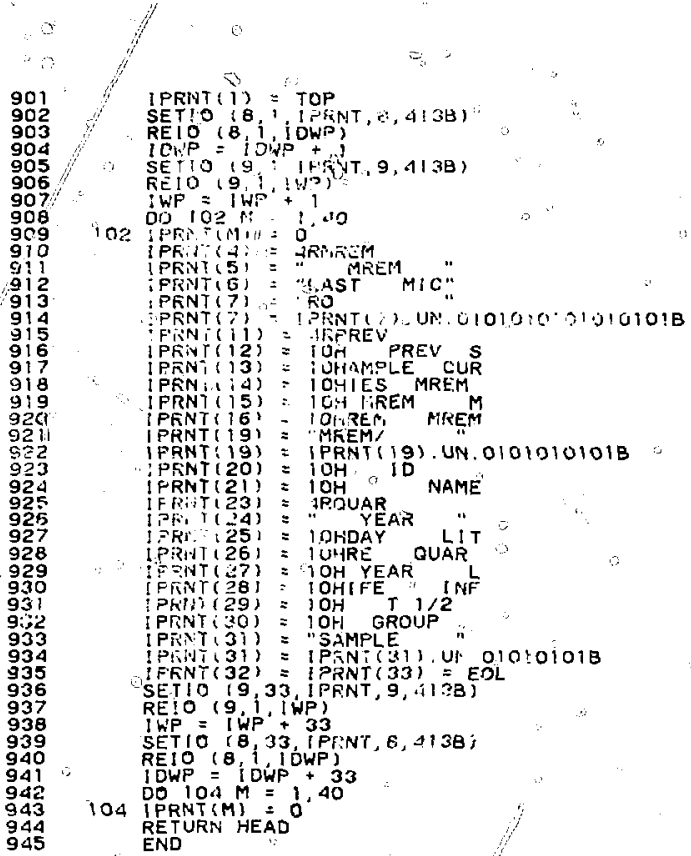

VRS/jn/sg/jf 